\title{
CONCEPTUAL FUNDAMENTALS OF INVESTMENT SUPPORT OF THE UKRAINIAN FOOD INDUSTRY
}

\author{
Olena Filatova ${ }^{1}$
}

\begin{abstract}
The purpose of the article is to develop the conceptual foundations of the investment support of the food industry of Ukraine on the basis of existing practice of statistical research. Methodology. The following analysis is carried out: evaluation of factors, overall assessment of the country's economic development prospects, absence of risks for investments due to military operations and other force majeure circumstances, stability of the legislative framework, etc. through interstate rating comparisons. Results. It is proved that the competitiveness of the country in the world market is not a sufficient condition for the development of investment support for the food industry. It is known that in the domestic market each industry competes with others for investment capital. Important factors, in this case, are: the capacity of the market, its growth prospects and the average level of profitability of economic activity. Thus, to attract both foreign and domestic investment, the food industry of Ukraine should correspond to a high level of these indicators, compared with other sectors of the economy. Within the framework of the developed concept this problem should be solved with the help of a multifactor model for assessing the competitiveness of the industry. Practical implications. According to calculations, the share of capital investments in the food industry in 2019 was $5.9 \%$ of their total volume in the economy. At the same time, food industry enterprises provided $8.2 \%$ of the country's gross domestic product and $11.6 \%$ of total production, including intermediate consumption. These comparisons show that today insufficient attention is paid to investment in this sector of the economy. Value/ originality. The methods proposed in the article, unlike the existing ones, are based on the use of a set of economic and mathematical methods and models and allow for a quantitative assessment of the proposed solutions.
\end{abstract}

Key words: agricultural products, food Industry, analysis of the dynamics of consumption, households.

JEL Classification: E42, Q01

\section{Introduction}

In the modern period of management, the analysis of existing and the search for new mechanisms of innovation and investment competitiveness in the food industry becomes extremely relevant. Representatives of this study are such domestic scientists as: L. Deineko, N. Demchuk, I. Irtyshcheva, O. Kovalenko, N. Kotkova, A. Kornyliuk, A. Kuznetsova and A. Podderogin. Among the main sources of their funding the authors note: own financial resources of enterprises, stock market, loans, including bank lending, budget financing, etc.

Despite the large number of scientific papers, the problem of effective investment support of the food industry in Ukraine, so far has not found a practical solution. Further research will be based on the conceptual construct fixed at the legislative level (Poddjerjoghin, Kornyljuk, 2009; Zavidna, Makarenko, Chepurda, Lyzunova, Shmygol, 2020; Shmygol, Galtsova, Varlamova, 2018).

So, according to the current Law of Ukraine "On Investment Activity", № 1560-XII of 18.09.1991, investments are all kinds of property and intellectual property, which are invested in the objects of economic and other activities aimed at generating profits or achieving a useful social or environmental effect. To such values the legislator includes: houses, buildings, movable and immovable property, money, shares and equities, other securities, except for bills of exchange, technical documentation and property rights, etc. According to this source, investment activity includes the whole range of practical actions of individuals and legal entities, as well as the state for implementation of investments.

\footnotetext{
Corresponding author:

${ }^{1}$ International University of Business and Law, Ukraine

E-mail: filatovaolena2021@gmail.com

ORCID: https://orcid.org/0000-0003-1460-7922
} 
In its practice, the State Statistics Committee of Ukraine uses the concept of capital investments and keeps appropriate records of economic entities by size, source of funding, areas of use and types of economic activity. These investments relate to capital investments, namely aimed at the creation, acquisition, reconstruction or technical re-equipment of fixed assets with a useful life of more than one year. Thus, by its economic content, capital investment at the macro-level is a component of final demand, the purpose of which is to provide the economy with fixed capital. At its expense depreciation deductions are made and gross fixed capital formation is financed.

\section{Analysis of sectoral development strategies}

Depending on the ratio of these indicators, there are the following strategies for sectoral development:

- capital investment exceeds depreciation (a growing economy based on increasing production capacity);

- capital investment equals depreciation (a static economy with constant production capacity);

- the necessary amount of depreciation is not covered by available capital investment (there is a reduction in the production base, which leads to economic recession).

According to the sources of investment, a distinction is made between: external, internal and own funds of enterprises:

- foreign investments can be made through the purchase of shares of domestic enterprises by nonresident investors or foreign investment funds in the course of their privatization, or the additional issue of shares. It can also be loans from nonresident banks for specific investment programs;

- domestic investments can be made from the state or local budgets, if the enterprises are state-owned, are the objects of state investment programs or are of national strategic or high social importance. Also, domestic investment includes the purchase of shares by resident investors or investment companies on the stock market of Ukraine, the activity of which in recent years has actually decreased, to service the public debt in the form of bonds. The bonds themselves are not directly related to investment activities. Debt financing includes bank credits and other loans for investment development programs;

- self-financing of expanded reproduction at the expense of own funds of enterprises is possible if according to the results of economic activity enterprises receive a net profit. This process is called reinvestment, which is decided by the owners. As for depreciation charges, as a component of capital investments, they are included in the cost of production.

In a market economy, any investment activity is based on economic feasibility. In general, an investor wants a stable and predictable return on investment. Thus, the investment attractiveness of the country, industry or a particular economic entity, determined by the relevant factors of competitiveness, comes to the fore.

For foreign investors, first of all, the investment attractiveness of the country is important, which is expressed in the following:

- ease of doing business and the ability to protect their rights in a civilized way, with the help of the judiciary system;

- an overall assessment of the country's economic development prospects;

- absence of risks for investments due to military operations and other force majeure circumstances, stability of the legal framework, etc.

These factors can be assessed by means of interstate rating comparisons, which are conducted annually by world-renowned and authoritative organizations and research centers.

\section{Conditions for the development of investment support for the food industry}

The country's competitiveness in the global market is not a sufficient condition for the development of investment support for the food industry. It is known that in the domestic market each industry competes with others for investment capital. Important factors in this case are: the capacity of the market, and its growth prospects and the average level of profitability of economic activity. Thus, to attract both foreign and domestic investments, the food industry of Ukraine should correspond to a high level of these indicators, in comparison with other sectors of the economy. Within the framework of the developed concept this problem should be solved by means of multifactor model of evaluation of competitiveness of the industry.

As for the factors of competitiveness that affect the amount of reinvestment at the expense of enterprises' own funds, their owners annually decide at a general meeting what share of retained earnings shall be directed to dividends 
and what share shall be left at the disposal of enterprises. The first direction characterizes the desire of investors to receive an annual return on investment. Accordingly, the second direction is reinvestment in future development. If the current level of profitability and business activity is maintained, an increase in the amount of capital available to companies will mean a corresponding increase in net profits in the medium term and the potential for more dividend payments in the future. Therefore, the main factors in the competitiveness of enterprises that promote the role of reinvestment and formation of fixed capital are:

- profitability, which is a prerequisite for expanded reproduction;

- confidence in the continuation of existing positive trends in the coming years, which is ensured by financial stability.

Quantitative assessment of the effectiveness of the proposed solutions can be given on the basis of the development of an appropriate dynamic model of reinvestment.

According to calculations, the share of capital investment in the food industry in 2019 was 5.9\% of their total amount in the economy. At the same time, food industry enterprises accounted for $8.2 \%$ of the country's gross domestic product and $11.6 \%$ of total production, including intermediate consumption. These comparisons show that today insufficient attention is paid to investment in this sector of the economy.

According to the current classifier NACE-2010, the food industry includes: production of food, beverages, and tobacco products. The largest share of capital investments in 2019 was in the production of food products and amounted to $82.6 \%$. More than $22 \%$ of this amount was in the production of meat products, and $16 \%$ in the production of oil and animal fat.

\section{Analysis of the volume of capital investments and their structure by uses and sources of funding}

Also, to fully determine the current state of investment activity in the industry, an analysis of capital investments and their structure by uses and sources of funding was conducted. The results of the first strand of the assessment, based on the 2015-2019 consolidated data, are presented in Table 1.

Table 1 shows that $98.7 \%$ of food processing companies' capital investments in 2019 were in tangible assets. The largest share was taken by: machinery and equipment (68.4\%), construction and reconstruction of buildings (20.0\%), existing buildings and structures (5.3\%), etc. The analysis of structural changes in the areas of investment that occurred in 2015-2019, columns (3) and (5) of Table 1, was conducted by statistical methods using the linear factor of particle growth. During this period, it was equal to $2.0 \%$, which indicates a fairly stable distribution of funds. The low level of investment in intangible assets is also evidence of the lack of attention paid in recent years to new technologies in production.

As for the sources of funding for capital investments, the corresponding structure for 2019 is shown in Table 2. The State Statistics Committee of Ukraine did not publish similar data for 2015.

Table 1

The structure of capital investment in the food industry in 2015-2019 by uses

\begin{tabular}{|c|c|c|c|c|}
\hline \multirow{2}{*}{ Investment areas } & \multicolumn{2}{|c|}{2015} & \multicolumn{2}{|c|}{2019} \\
\hline & million UAH. & $\%$ & million UAH. & $\%$ \\
\hline 1 & 2 & 3 & 4 & 5 \\
\hline Capital investments in tangible assets, million UAH, including: & 14021,2 & $97,34 \%$ & 30426,3 & $98,71 \%$ \\
\hline in land ownership & 50,1 & $0,35 \%$ & 70,6 & $0,23 \%$ \\
\hline in existing buildings and structures & 310,9 & $2,16 \%$ & 1635,8 & $5,31 \%$ \\
\hline in the construction and reconstruction of buildings & 3804,8 & $26,41 \%$ & 6148,1 & $19,95 \%$ \\
\hline in machinery and equipment & 9270,0 & $64,35 \%$ & 21072,9 & $68,37 \%$ \\
\hline in other tangible assets & 585,4 & $4,06 \%$ & 1498,9 & $4,86 \%$ \\
\hline Capital investments in intangible assets, million UAH, including: & 383,5 & $2,66 \%$ & 396,4 & $1,29 \%$ \\
\hline in patents, licenses, trademarks & 158,6 & $1,10 \%$ & 130,1 & $0,42 \%$ \\
\hline in purchasing software & 155,7 & $1,08 \%$ & 122,6 & $0,40 \%$ \\
\hline in other intangible assets & 69,2 & $0,48 \%$ & 143,7 & $0,47 \%$ \\
\hline Total capital investments & 14404,7 & $100,00 \%$ & 30822,8 & $100,00 \%$ \\
\hline
\end{tabular}


Table 2

The structure of capital investment in the food industry in 2019 by source of funding

\begin{tabular}{|l|c|}
\hline \multicolumn{1}{|c|}{ Sources of funding } & Specific weight, $\%$ \\
\hline State budget funds & $0,06 \%$ \\
\hline Funds from local budgets & $0,01 \%$ \\
\hline Own funds of enterprises & $93,54 \%$ \\
\hline Bank loans and other credits & $5,10 \%$ \\
\hline Funds of investment companies, funds and non-resident investors & $1,27 \%$ \\
\hline Other sources of funding & $0,02 \%$ \\
\hline
\end{tabular}

As shown in Table 2, the main source of funding for investment in the food industry in Ukraine are own funds of enterprises and organizations, where their share in 2019 was more than $93 \%$.

The second most important source is bank loans and other credits, which account for about 5\%. They also include loans from non-resident banks. In 2018, their share in loans was $13.4 \%$. In 2019, such data was not disclosed to ensure the confidentiality of statistical information, according to the Law of Ukraine "On State Statistics". Similarly, no separate data on nonresident investors' funds were published in 2019. Therefore, there is no accurate data on foreign investment, but their share did not exceed $6.4 \%$.

It was noted earlier that at the macro-level investment is used to finance depreciation charges and gross fixed capital formation, which is used to increase production capacity and ensure economic growth of industries and the economy as a whole. Data on the latter indicator, by economic activity, are contained in the annual "Expenditure-Output" tables. According to the results of the calculations, it was found that during 2015-2019, the relative level of gross fixed capital formation to the country's GDP gradually increased from $13.5 \%$ to $17.6 \%$. The greatest growth occurred in construction, machine building and some other types of manufacturing industry. As for the food industry, during this period the indicator was zero. This means that today, due to the current state of investment security, enterprises in this sector do not have objective prerequisites for economic growth.

\section{Conclusions}

The place and importance of the state in ensuring the long-term development of the food industry of Ukraine is related to the need to guarantee food security. In the modern history of independent Ukraine there are examples when foreign investment in domestic machine-building and smelting enterprises, with the acquisition of a controlling stake by non-resident investors, subsequently led to the bankruptcy of these enterprises. The mass character of such cases indicates that these cases are not accidental, but also that it is a form of hybrid economic warfare against Ukraine by neighboring states. Therefore, it is necessary to constantly monitor this situation with the help of a model for assessing the food supply and forcibly restricting the rights of individual foreign investors to conduct business activities in Ukraine.

Summing up, the scientific novelty of this work is the development of the concept of investment support of food industry in Ukraine on the basis of existing practice of statistical research, which, unlike existing ones, is based on a set of economic and mathematical methods and models, which allows quantitative assessment of the proposed solutions.

\section{References:}

Dejneko, L. V., \& Irtyshheva, I. O. (2009). Mekhanizm vprovadzhennja innovacijnykh tekhnologhij $\mathrm{v}$ prodovoljchu sferu: sutnistj, funkciji, zavdannja i reghionaljni osoblyvosti [The mechanism of introduction of innovative technologies in the food sphere: essence, functions, tasks and regional features]. Mekhanizm reghuljuvannja ekonomiky - Mechanism of economic regulation, 2(40), 123-131.

Demchuk, N. (2014). Strateghichne planuvannja ta orghanizacijno-ekonomichnyj mekhanizm investycijnoji dijaljnosti kharchovykh pidpryjemstv [Strategic planning and organizational and economic mechanism of investment activity of food enterprises]. Ukrajinsjka nauka: mynule, suchasne, majbutnje (electronic journal), 19(1), 17-24. Available at: http://nbuv.gov.ua/UJRN/Un_ msm_2014_19(1)_5 
Kovalenko, O. V., \& Kotkova, N. S. (2020). Innovacijno-investycijne zabezpechennja tekhnichnoji modernizaciji jak osnova zrostannja konkurentospromozhnosti kharchovoji promyslovosti [Innovation and investment support of technical modernization as a basis for increasing the competitiveness of the food industry]. Prodovoljchi resursy - Food resources, 14, 230-240. Available at: http://nbuv.gov.ua/ $\mathrm{UJRN} /$ pr_2020_14_26

Kuznjecova, A. Ja. (2004). Dejaki aspekty finansuvannja investycijno-innovacijnykh proektiv za rakhunok vlasnykh koshtiv pidpryjemstv [Some aspects of financing investment and innovation projects at the expense of own funds of enterprises]. Aktualjni problemy ekonomiky - Actual problems of economy, 7(37), 42-52.

Poddjerjoghin, A. M., \& Kornyljuk, A. V. (2009). Innovaciji ta jikh finansove zabezpechennja u kharchovij promyslovosti Ukrajiny [Innovations and their financial support in the food industry of Ukraine]. Finansy Ukrajiny - Finance of Ukraine, 11, 94-100.

Zavidna, L., Makarenko, P. M., Chepurda, G., Lyzunova, O., \& Shmygol, N. (2020). Strategy of innovative development as an element to activate innovative activities of companies. Academy of Strategic Management Journal, 18(4), 1-6.

Shmygol, N., Galtsova, O., \& Varlamova, I. (2018). Developing a methodology to assess the environmental and economic performance index based on international research to resolve the economic and environmental problems of Ukraine. Baltic Journal of Economic Studies, 4(4), 366-374. DOI: https://doi.org/10.30525/2256-0742/2018-4-4-366-374

Shmygol, N., Galtsova, O., Solovyov, O., Koval, V., \& Arsawan, I. (2020). Analysis of country's competitiveness factors based on inter-state rating comparisons. E3S Web Conferences, 153, 03001. 